\title{
PARKI TEMATYCZNE NA MIEJSKICH TERENACH POKOPALNIANYCH SOSNOWCA I ZIELONEJ GÓRY
}

\author{
Monika E. Drozdek¹, Andrzej Greinert ${ }^{\bowtie 2}$, Jakub Kostecki², \\ Agnieszka Tokarska-Osyczka³, Róża Wasylewicz ${ }^{2}$ \\ ${ }^{1}$ Instytut Zarządzania i Inżynierii Rolnej, Państwowa Wyższa Szkoła Zawodowa w Sulechowie, Sulechów \\ ${ }^{2}$ Wydział Budownictwa, Architektury i Inżynierii Środowiska, Uniwersytet Zielonogórski, Zielona Góra \\ ${ }^{3}$ Pracownia Architektury Krajobrazu Zielony Adres, Zielona Góra
}

\begin{abstract}
STRESZCZENIE
W pracy ukazano możliwości zagospodarowania terenów pokopalnianych w dwóch polskich miastach średniej wielkości - Sosnowcu i Zielonej Górze. Teren w Sosnowcu obejmuje część dawnej Kopalni Węgla Kamiennego „Niwka”, natomiast w Zielonej Górze - dawnej cegielni „Krośnieńska” i kopalni węgla brunatnego, działających w ramach Consolidierte Grünberger Gruben. Współcześnie tereny te są nieużytkami, o silnie zdegradowanej powierzchni ziemi. Autorzy artykułu zaproponowali wobec nich zagospodarowanie parkowe, z pozostawieniem elementów ich przeszłości przemysłowej. Tym samym, poza rekreacją i wypoczynkiem, obszary te nabiorą cech ciekawych, unikatowych parków tematycznych nawiązujących do przemysłowej historii miast.
\end{abstract}

Słowa kluczowe: tereny poprzemysłowe, deindustrializacja, rewitalizacja, tereny zieleni

\section{WSTĘP}

Intensywny rozwój przemysłu doprowadził do bardzo dużych zmian w przestrzeniach miejskich, zwłaszcza na obszarach bogatych w zasoby naturalne. W Europie Środkowej okresem najszybszego powiększania się terenów przemysłowych była druga połowa XIX i początek XX wieku. Proces ten miał charakter chaotycznego zajmowania coraz szerszych przestrzeni, przy braku poszanowania dla środowiska przyrodniczego i reguł kształtowania ładu przestrzennego. Przekształcenia wtedy zapoczątkowane jeszcze obecnie stwierdzane są w postaci licznych przekształceń powierzchni ziemi (Greinert, 2000, 2015). Te ostatnie następowały wielokrotnie, w toku budowy zakładów, a następnie burzenia jednych przedsięwzięć i budowy na ich miejscu kolejnych (Domański, 2000). Po przeniesieniu zakładów przemysłowych z miast na obszary wobec nich peryferyjne we wszystkich krajach przechodzących deindustrializację miast wiele $\mathrm{z}$ terenów pozostawiono w formie nieużytków (De Sousa i Ghoshal, 2012; Ozden, 2012). Przyniosło to szereg negatywnych skutków w postaci zmian w krajobrazie. Wobec terenów położonych poza głównymi osiami inwestycyjnymi (bliskość centrum miasta, lotniska, dworca kolejowego, tras szybkiego ruchu) mają one charakter trwały (Frantál i in., 2015).

Liczne zakłady przemysłowe nie przetrwały zmian geopolitycznych po II wojnie światowej oraz przemian ustrojowych w Polsce początku lat 90. XX wieku. W większości przypadków oznaczało to porzucenie terenów, z których część znalazła możliwość zmiany formy zagospodarowania, inne niestety nie (Domański, 2009).

凶a.greinert@iis.uz.zgora.pl 
Pozostały jako strefy problemowe na terenach zurbanizowanych, utrudniające komunikację, a nierzadko też zagrażające bezpieczeństwu mieszkańców. Największe problemy z nimi związane wystąpiły na terenach miast-powiatów grodzkich, zwłaszcza w tych silnie niegdyś uprzemysłowionych, jak: śląskie, łódzkie, mazowieckie, lubuskie i kujawsko-pomorskie (Jarczewski, 2009). Wśród pozostawionych terenów poprzemysłowych ważną pozycję zajmują tereny po wydobyciu surowców naturalnych, trudne do zagospodarowania za sprawą szeregu wadliwych charakterystyk geotechnicznych oraz przestrzennych.

Odpowiedzią na te niekorzystne sytuacje jest realizacja działań rewitalizacyjnych, w początku XXI wieku najbardziej zaawansowana na terenach miejskich (Lorens, 2010; De Sousa i Ghoshal, 2012; Muszyńska-Jeleszyńska, 2015). Część z tych programów zostało umiejscowionych w szerszych perspektywach europejskich, jak: ReTInA - Revitalisation of Traditional Industrial Areas (Lorber, 2014), URBAN II, GREENKEYS, EUROSCAPES czy PERIURBAN PARK (Greinert i Drozdek, 2015). W zdecydowanej większości miast Polski sformułowano Lokalne Programy Rewitalizacji jako elementy Regionalnych Programów Operacyjnych, współfinansowanych ze środków Unii Europejskiej (Dej, Huculak, Janas, Jarczewski i Ziobrowski, 2013; Ciesiółka i Rogatka, 2015). Rewitalizacja większości obszarów poprzemysłowych poprzedzona jest cyklem prac rekultywacyjnych z uwagi na stwierdzaną wieloczynnikową degradację powierzchni ziemi (Greinert, 2000; GTZ, 2003; Maciejewska i Turek, 2014; Skalny i Białecka, 2015). Dotyczy ona zarówno antropogenicznych zmian rzeźby terenu, w tym utworzenia hałd i zagłębień, jak i zanieczyszczenia gleb (Pancewicz, 2012). Większość problemów dotyczących jej stanu nie kończy się z ustaniem pracy zakładów, a wręcz przeciwnie - potrafi się znacząco nasilić, głównie wskutek degradacji budynków, budowli i innych elementów infrastruktury technicznej. Modernizacja przestrzeni publicznych i poprawa stanu środowiska wraz z zachowaniem dziedzictwa kulturowego to ważne cele rewitalizacji ze sfer społeczno-gospodarczych i ekologiczno-przestrzennych (Pancewicz, 2012). Szereg planów i projektów zaproponowano podczas spotkań branżowych, jak IBA (Internationale Bauausstellung = Międzynarodowa Wystawa Budowlana) czy BUGA (Bundesgartenschau $=$ Federalna Wystawa Ogrodnicza) - Pancewicz (2012). W nowej perspektywie finansowej UE rewitalizacja terenów miejskich i wiejskich obecna jest w Programie Operacyjnym „Pomoc techniczna 2014-2020” i Regionalnych Programach Operacyjnych Województw, zarówno w aspektach planistycznych i projektowych, jak i wdrożeniowych w różnej skali (PFE, 2016). Niektóre regiony zdecydowały się zrealizować zadania rewitalizacyjne wpisujące się w ideę Europejskich Szlaków Dziedzictwa Przemysłowego czy też lokalne idee Szlaków Zabytków Techniki (woj. śląskie) i Muzeów Techniki (Baborska-Norożny, 2012).

Na niektórych obszarach miejskich zdecydowano wykorzystać zdegradowane tereny dawnych zakładów przemysłowych do konstrukcji nowych założeń parkowych o funkcji rekreacyjno-wypoczynkowej i estetyzujących miasto (Huculak, 2009; Gallagher, Pechmann, Holzapfel i Grabosky, 2011; Ozden, 2012; MuszyńskaJeleszyńska i Jasińska, 2013; Maciejewska i Turek, 2014; Atkinson, Doick, Burningham i France, 2014). Cechą szczególną takich założeń jest możliwość pozostawienia części dawnych zakładów w formie zabytków historii, świadczących o niegdyś przemysłowym charakterze miasta. Obiekty w dobrym stanie można adaptować do innej funkcjonalności, np. usługowej czy mieszkaniowej, rozszerzając funkcjonalność obszaru. Wszystkie te działania mają szczególne znaczenie dla ochrony dziedzictwa narodowego, zwłaszcza w miastach, które wskutek różnych zdarzeń całkowicie lub w większości utraciły rolę ośrodków przemysłowych. Tereny po rewitalizacji, poza funkcjami rekreacyjną i wypoczynkową, nabierają także znaczenia edukacyjnego i sentymentalnego, związanego z poznawaniem historii regionów. Tego rodzaju zagospodarowanie ma też niebagatelne znaczenie dla poprawy jakości ekologicznej miast, a tym samym odtwarzania korytarzy ekologicznych w dużej mierze zatraconych $\mathrm{w}$ dobie intensywnej industrializacji.

Dla ilustracji możliwej transformacji terenów poprzemysłowych w miastach Polski średniej wielkości opisane zostaną dwa przykłady związane z uporządkowaniem terenów pokopalnianych w Sosnowcu i Zielonej Górze i nadaniem im nowej funkcjonalności parkowej. Celem pracy jest przedstawienie koncepcji rewitalizacji przyrodniczej względnie dużych obszarów miejskich, zgodnie z wizją zrównoważonego rozwoju i użytkowania 
Drozdek, M. E., Greinert, A., Kostecki, J., Tokarska-Osyczka, A. i Wasylewicz, R. (2017). Parki tematyczne na miejskich terenach pokopalnianych Sosnowca i Zielonej Góry. Acta Sci. Pol. Architectura, 16 (1), 65-77. doi: 10.22630/ASPA.2017.16.1.07.

terenu, przy poszanowaniu ich wartości historycznych. Zdaniem autorów możliwe jest zaaranżowanie na terenach dawnych zakładów przemysłowych parków rekreacyjno-wypoczynkowych z unikalnym przekazem historycznym. Dzięki takiemu działaniu uda się odzyskać te obszary dla społeczności lokalnych, nadać im pożądaną formę, poprawiając przy okazji wizerunek miast, a także połączyć pokolenia na bazie prezentacji osiągnięć dawnych ich mieszkańców.

\section{MATERIA I METODY}

Przeprowadzono analizę dwóch terenów pokopalnianych, zlokalizowanych na terenach miast Sosnowiec i Zielona Góra, pod względem możliwości ich zrewitalizowania w kierunku urządzenia na nich historycznych parków tematycznych.

Teren po Kopalni Węgla Kamiennego „Niwka” zlokalizowany jest w Sosnowcu, w dzielnicy Niwka, przy ulicach Kopalnianej i Wojska Polskiego (rys. 1). Jego granicę wschodnią i północną tworzy linia kolejowa, przebiegająca częściowo w wykopie, częściowo na nasypie. Powierzchnia terenu wynosi 29,75 ha. Teren jest płaski, przy wysokości minimalnej 250,4 m n.p.m. i maksymalnej 258,0 m n.p.m., z lokalnymi zagłębieniami do $5 \mathrm{~m}$ wysokości względnej. Na północ od torowiska zlokalizowany jest park miejski „Niwka”. Na południowo-zachodnim krańcu obszar sąsiaduje z zabudową wielorodzinną typu blokowego osiedla Kozibąka, na południowym - dzielnicy Niwka, a na południowo-wschodnim - z zabudowa jednorodzinną dzielnicy Bobrek. Właścicielem terenu jest syndyk upadłościowy Kopalni Węgla Kamiennego Niwka-Modrzejów.
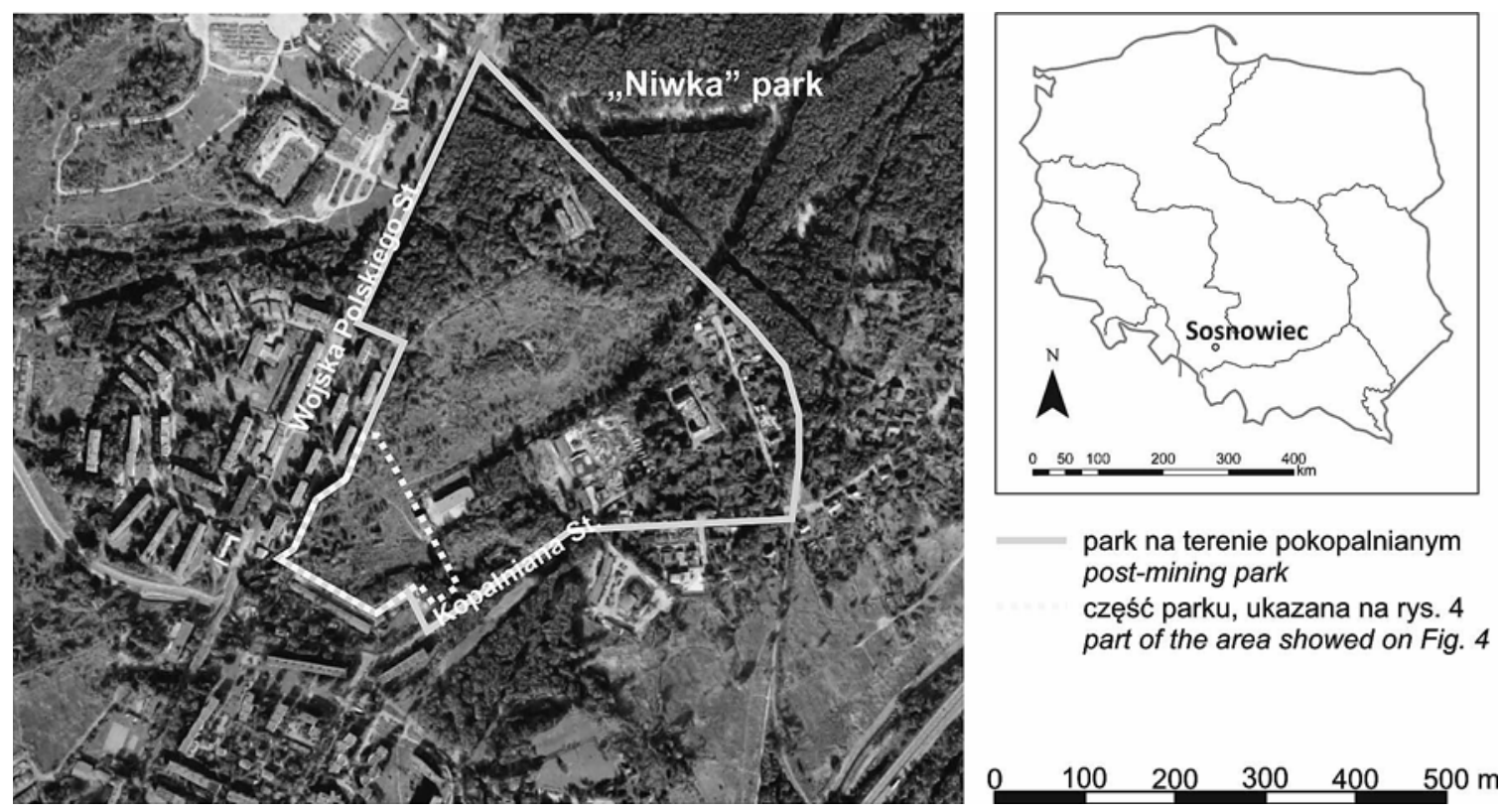

Rys. 1. Lokalizacja terenu poprzemysłowego w Sosnowcu

Fig. 1. Location of the post-industrial area in Sosnowiec

Teren dawnej cegielni wraz z kopalnią gliny zlokalizowany jest w Zielonej Górze na osiedlu Na Cegielni, w rejonie ulic: Fajansowej, Ceramicznej, Klinkierowej, Porcelanowej, Hoffmana i Keramzytowej oraz na terenach lasów państwowych sąsiadujących z osiedlem (rys. 2). Właścicielami posesji mieszkalnych są indywidualni mieszkańcy miasta, części wspólnych natomiast - miasto Zielona Góra, Lasy Państwowe i gmina Świdnica. 
Drozdek, M. E., Greinert, A., Kostecki, J., Tokarska-Osyczka, A. i Wasylewicz, R. (2017). Parki tematyczne na miejskich terenach pokopalnianych Sosnowca i Zielonej Góry. Acta Sci. Pol. Architectura, 16 (1), 65-77. doi: 10.22630/ASPA.2017.16.1.07.

Teren ze wszystkich stron graniczy z powierzchniami zalesionymi. To nierzadka sytuacja z uwagi na 55-procentowy udział lasów w powierzchni całkowitej miasta. Powierzchnia terenu wynosi około 30 ha. Deniwelacje na terenie sięgają $15-20 \mathrm{~m} \cdot 50 \mathrm{~m}^{-1}$, przy wysokości minimalnej $135 \mathrm{~m}$ n.p.m. i maksymalnej $160 \mathrm{~m}$ n.p.m.
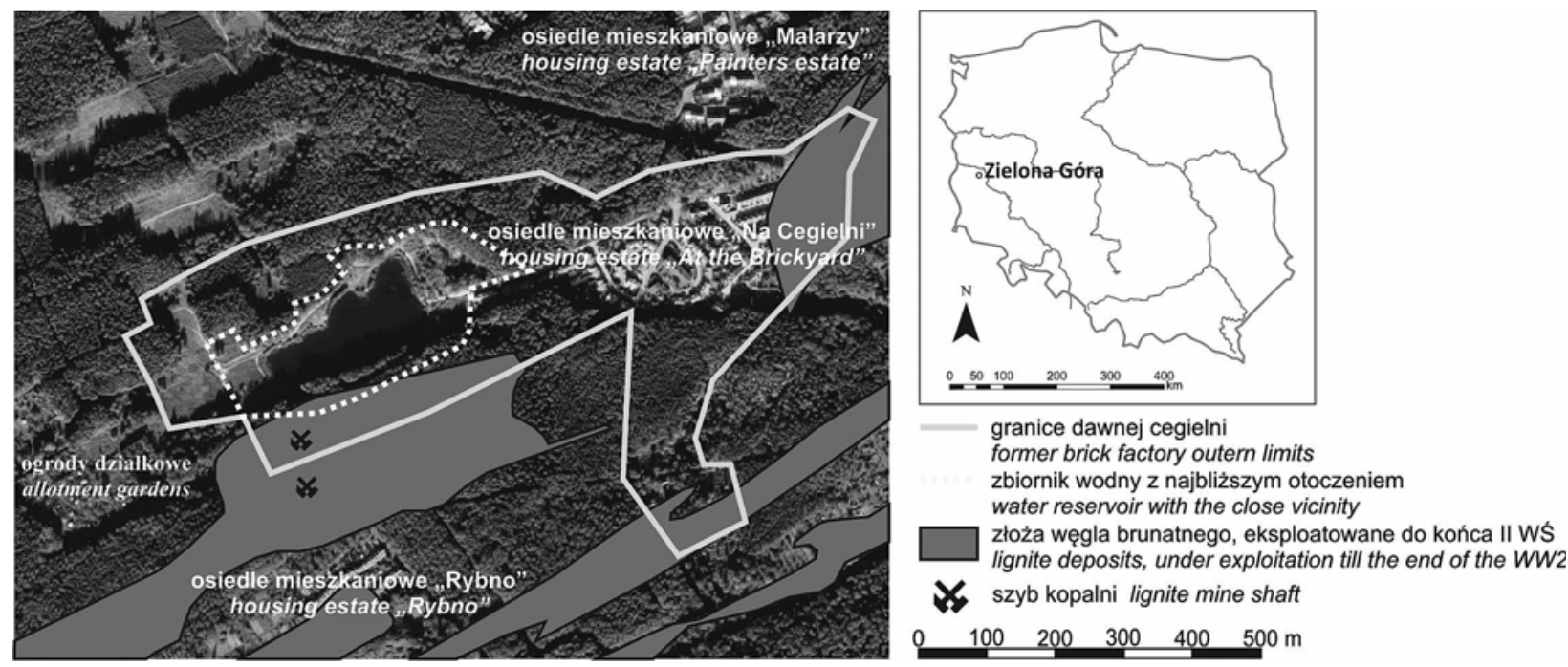

Rys. 2. Lokalizacja terenu poprzemysłowego w Zielonej Górze

Fig. 2. Location of the post-industrial area in Zielona Góra

Każdy z obszarów opisano na podstawie badań historycznych, planistycznych, kartograficznych oraz terenowych przeprowadzonych przez Kozińską i Greinerta (2013) dla terenu w Sosnowcu i autorów niniejszego artykułu dla terenu zielonogórskiego. Wynikiem tych działań jest niniejsze, autorskie opracowanie uwarunkowań funkcjonalno-przestrzennych wybranych terenów poprzemysłowych. $\mathrm{Na}$ ich podstawie przeprowadzono analizę możliwości konstrukcji założeń parkowych na podstawie pozostawionych terenów. Kolejno wskazano: dla Sosnowca - koncepcję projektową przyszłego zagospodarowania terenu (Kozińska i Greinert, 2013, zmodyf. przez autorów artykułu), a dla Zielonej Góry - nową koncepcję projektową niedokończonej inwestycji z początku XXI wieku.

\section{WYNIKI BADAŃ}

\section{Studium terenu w Sosnowcu}

Na początku XIX wieku (ok. 1860 r.) na obszarze dzisiejszego miasta Sosnowiec powstała Kopalnia Węgla Kamiennego „Niwka”, funkcjonująca przez ponad sto lat. W 1999 roku kopalnia została zamknięta i zlikwidowana. Teren przez nią zajęty przez ponad 10 lat pokrył się roślinnością ruderalną i stracił walor funkcjonalności. Obszar nie jest miejscem atrakcyjnym również ze względu na degradację powierzchni ziemi, w tym zaśmiecenie. Negatywny odbiór tych terenów pogłębia ich położenie wśród kwartałów mieszkalnych miasta (rys. 1).

Powierzchnia po byłej Kopalni KWK „Niwka” nie jest ukształtowana równomiernie: po stronie południowej teren odznacza się płaską powierzchnią, natomiast część centralna jest pofałdowana, co zostało spowodowane wykopywaniem uzbrojenia terenu. Na północy, zachodzie, w części południowo-zachodniej oraz wschodniej teren wyróżnia się niewielkimi wzniesieniami także powstałymi za sprawą przekopywania gruntu. Nierówności spowodowane są również przez nawiezienie gruzu, zarośniętego obecnie roślinnością (rys. 3). Krajobraz terenu 
Drozdek, M. E., Greinert, A., Kostecki, J., Tokarska-Osyczka, A. i Wasylewicz, R. (2017). Parki tematyczne na miejskich terenach pokopalnianych Sosnowca i Zielonej Góry. Acta Sci. Pol. Architectura, 16 (1), 65-77. doi: 10.22630/ASPA.2017.16.1.07.

jest poprzecinany rowami po uzbrojeniach terenu oraz nieckami wywołanymi zapadaniem się terenu. W nieckach czasowo stagnują wody opadowe, co powoduje utrudnienia komunikacyjne - teren jest odwiedzany przez mieszkańców okolicznych osiedli, głównie w ramach spacerów z psami (Kozińska i Greinert, 2013).

Obszar w części południowej i centralnej pokryty jest roślinnością ruderalną i synantropijną, z przewagą w piętrze wyższym samosiewów brzozy brodawkowatej, robinii białej, wierzby białej, klonu jesionolistnego, topoli balsamicznej oraz rokitnika pospolitego.
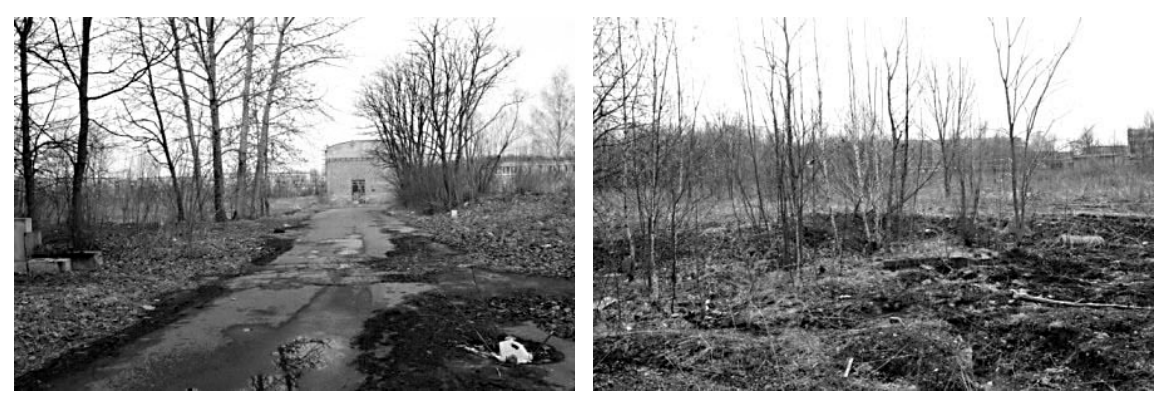

Rys. 3. Krajobraz terenu poprzemysłowego dawnej KWK „Niwka” (fot. Kozińska, 2011)

Fig. 3. Post-industrial landscape of the former "Niwka" coal mine (photo Kozińska, 2011)

Dla terenu byłej KWK „Niwka” brak jest miejscowych planów zagospodarowania przestrzennego. Według Studium Uwarunkowań i Kierunków Zagospodarowania Przestrzennego (Uchwała 2003) obszar należy do grupy terenów kopalń węgla kamiennego (bez szybów peryferyjnych), zwalnianych przez funkcjonujące przedsiębiorstwa, oraz terenów poprzemysłowych powstałych w wyniku całkowitej likwidacji zakładów. Dokument ten nie określa docelowych funkcji ani wskaźników urbanistycznych dla opisywanego obszaru.

Problemem wobec opisywanego obszaru jest silne, trwałe antropogeniczne przekształcenie powierzchni ziemi. Dodatkowe wyzwania wynikają z zanieczyszczenia powierzchni odpadami komunalnymi, powydobywczymi i budowlanymi, zdeponowanymi na wierzchu, jak też wymieszanymi z niżej zalegającymi warstwami gruntowymi. Zadaniem działań rekultywacyjnych jest stworzenie korzystnych warunków do rozwoju procesów biologicznych w górnej części gleby i ich podtrzymywania. Czynności te mają na celu nadanie kształtu powierzchni zgodnie z zaplanowanymi pracami, uformowanie prawidłowych warunków powietrzno-wodnych, chemiczno-fizycznych oraz zapewnienie bezpieczeństwa chemicznego i biologicznego.

Mieszkańcy pragnęliby, aby na terenie po byłej Kopalni Węgla Kamiennego „Niwka” powstał park z miejscami rekreacyjno-sportowymi. Będzie to możliwe po przeprowadzeniu rekultywacji powierzchni ziemi, obejmującej usunięcie odpadów, pozostałości elementów infrastruktury i obiektów budowlanych zagrażających przyszłym użytkownikom obszaru, dostosowaniu reliefu do przyszłych funkcji, oczyszczeniu gleb z zanieczyszczeń. W rezultacie dalszych działań teren zostanie zagospodarowany w formie parku rekreacyjno-sportowego, który byłby przedłużeniem starego parku kopalnianego „Niwka” (rys. 1 i 4). Jest to zgodne z ogólnoświatowym trendem nieorganizowania terenów przemysłowych w granicach mieszkalno-usługowych sektorów miejskich. Park umożliwi aktywny wypoczynek, przy okazji poprawiając komunikację międzyosiedlową.

We wschodniej części sosnowieckiej kopalni znajduje się stary szyb, dla którego zostanie wykonany oddzielny projekt rewaloryzacji. Szyb ma zostać przekształcony w pomnik upamiętniający górników, którzy zginęli w sosnowieckich kopalniach, oraz na muzeum przedstawiające historię kopalni. Wnętrza parkowe zostaną ukształtowane w sposób odmienny dla sektorów wypoczynkowych, rekreacji aktywnej, użytkowania sportowego i towarzyszących pozostawionym elementom przemysłowym. Ścieżki w parku zostaną poprowadzone między kolejnymi, zaprojektowanymi elementami, doprowadzając do każdego punktu w parku. Roślinność drzewiastą 


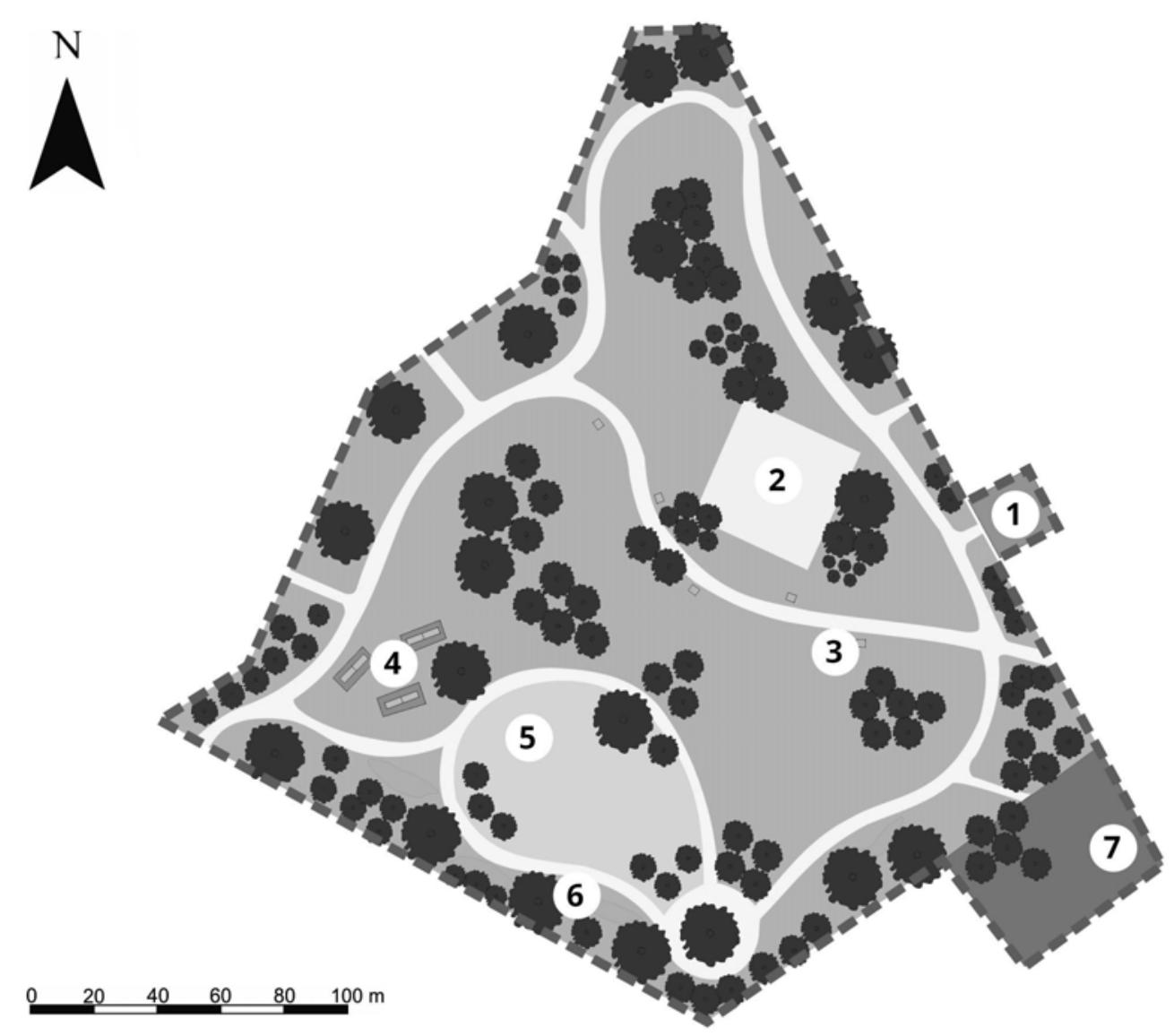

Rys. 4. Koncepcja zagospodarowania południowej części terenu po KWK „Niwka” w Sosnowcu: 1 - szyb kopalni, 2 - plac zabaw, 3 - stoły szachowe, 4 - stoły do ping-ponga, 5 - skatepark, 6 - parkour, 7 - parking (oprac. Kozińska i Greinert, 2013, zmod.)

Fig. 4. Area development design of the southern part of former "Niwka" coal mine in Sosnowiec: 1 - mine shaft, 2 - play ground, 3 - chess tables, 4 - ping-pong tables, 5 - skatepark, 6 - parkour, 7 - parking (elab. Kozińska and Greinert, 2013, mod.)

i krzewiastą zaprojektowano tak, aby tworzyła klomby, grupy oraz gaje. Między wszystkim elementami parku zostanie posiana mieszanka traw rekreacyjnych, na której będzie można organizować pikniki oraz odpoczywać na kocach. W całym parku zaplanowano posadzenie soliterów i małych grup drzew - przy placu zabaw, stołach betonowych, boiskach, zbiorniku wodnym oraz w innych jego częściach. Celem tak zaprojektowanej zieleni jest uzyskanie efektu naturalistycznej kompozycji z powierzchnią zadrzewioną po stronie wschodniej i południowej. W przypadku strony zachodniej i południowej roślinność ma na celu odgrodzenie parku od nieatrakcyjnego widoku.

Na terenie przyszłego parku zostanie poprowadzona sieć energetyczna, doprowadzająca prąd elektryczny do lamp przy ścieżkach, placu zabaw, boiska, do nabrzeża zbiornika wodnego oraz starego szybu pokopalnianego. $\mathrm{Na}$ terenie byłej kopalni zostanie także poprowadzona sieć teletechniczna, umożliwiająca swobodne korzystanie $\mathrm{z}$ Internetu. Realizacja tego ostatniego zamierzenia jest możliwa do zrealizowania w formie mieszanej: transmisja przewodowa i bezprzewodowa lub tylko w postaci sieci bezprzewodowej z jednym lub wieloma punktami dystrybucji sygnału. 
Drozdek, M. E., Greinert, A., Kostecki, J., Tokarska-Osyczka, A. i Wasylewicz, R. (2017). Parki tematyczne na miejskich terenach pokopalnianych Sosnowca i Zielonej Góry. Acta Sci. Pol. Architectura, 16 (1), 65-77. doi: 10.22630/ASPA.2017.16.1.07.

\section{Studium terenu w Zielonej Górze}

Udokumentowana historia wydobycia iłów na potrzeby produkcji wyrobów ceramicznych sięga na tym terenie XIX wieku. Wcześniej odbywało się to w rejonach położonych bliżej ówczesnej zabudowy miasta. Prowadzono też tutaj szeroko zakrojone badania terenu związane z poszukiwaniem, a następnie wydobyciem występującego w tym rejonie węgla brunatnego, eksploatowanego niemal do końca II wojny światowej metodą głębinową (kopalnie/szyby: Kleine Agathe, Emilie, Friedrich Wilhelm, Otto, Karl, Bahn, Schwidtal, 7, 8/9, 11, 13, 15, Schacht X, Victoria, Alexander, należące do Consolidierte Grünberger Gruben) - Bujkiewicz (1997) i Gontaszewska (2015). Szereg niecek zapadliskowych na trasach dawnych chodników górniczych obecnych jest w lasach okalających teren dawnej cegielni.

Obecnie teren jest podzielony między wielu właścicieli, co utrudnia zagospodarowanie całości w spójny sposób. Tym niemniej w toku formowania osiedla mieszkaniowego i zaraz po tym uporządkowano zbiornik wodny i wykonano rekultywację jego bezpośredniej okolicy. Na terenie osiedla $\mathrm{Na}$ Cegielni ustawiono maszyny niegdyś używane do transportu iłów i formowania cegieł (rys. 5). Samo osiedle nawiązuje do przemysłowej przeszłości poprzez nazwy ulic, a także wybudowanie centralnego domu wielorodzinnego bezpośrednio w dawnym budynku pieca do wypalania cegieł (pieca Hoffmana). Lasy Państwowe wykonały szereg ścieżek i dróg na terenach lasów przyległych do opisywanej powierzchni parkowej, łącząc zbiornik wodny z nieodległymi osiedlami mieszkaniowymi. Prowadzona jest planowa gospodarka leśna. Pozostaje kwestia uporządkowania drzewostanu przyległego do osiedla i zbiornika z robinią akacjową, jako gatunkiem dominującym, i z dziko uformowanym podszytem - częściowo przez samych mieszkańców, sadzących tam żywotniki, świerki i jałowce. W toku opracowywania strategii rozwoju zieleni w mieście zapisano ten obszar jako wyjątkowo cenny pod względem potencjału przyrodniczego i parkowego (Greinert i Drozdek, 2015).
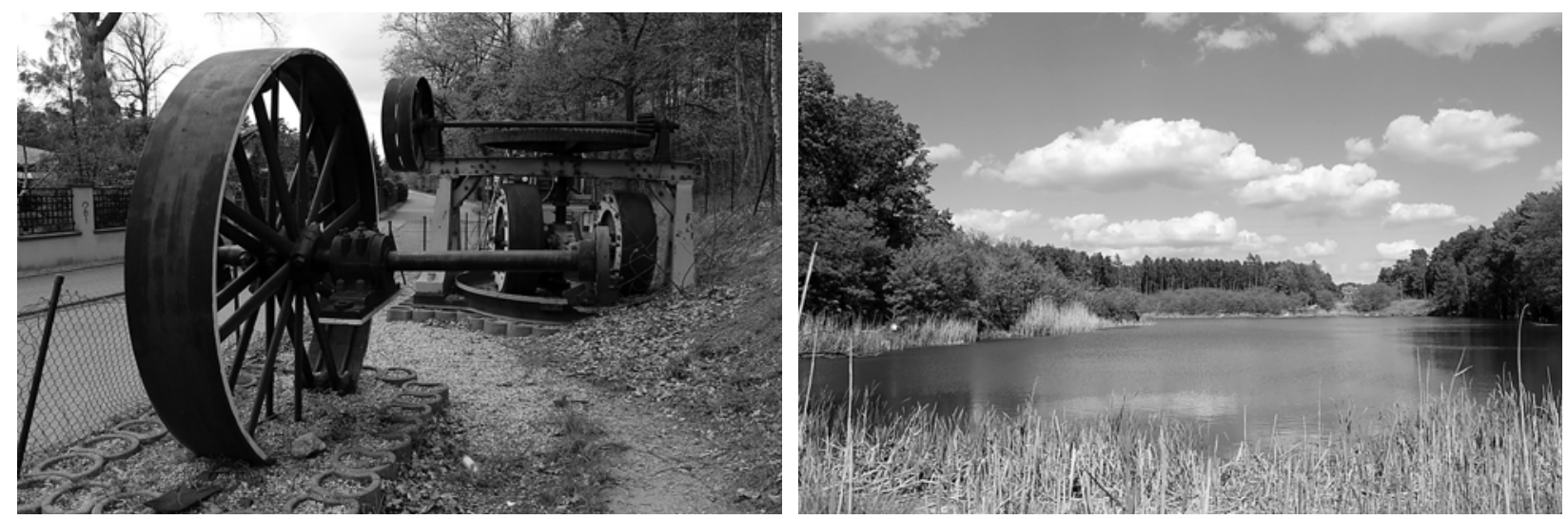

Rys. 5. Współczesny krajobraz terenu poprzemysłowego dawnej cegielni „Krośnieńska”

Fig. 5. Contemporary landscape of the post-industrial area of former "Krośnieńska” brick factory

W Studium uwarunkowań i kierunków zagospodarowania przestrzennego (Studium, 2008, zm. 2014) obszar mieści się w strefie ekstensywnej urbanizacji miejskiej, obejmując tereny dominacji zabudowy mieszkaniowej jednorodzinnej, parków leśnych i teren stawu. Dla dwóch ostatnich przewidziano rekreacyjny kierunek zagospodarowania, z wprowadzeniem ścieżek pieszych i rowerowych na terenach leśnych.

Zgodnie z zapisami Strategii rozwoju terenów zieleni w mieście Zielona Góra (Greinert i Drozdek, 2015), opisywany teren został uznany za jeden z cenniejszych w mieście - o bardzo dużym potencjale rekreacyjnowypoczynkowym. 
Drozdek, M. E., Greinert, A., Kostecki, J., Tokarska-Osyczka, A. i Wasylewicz, R. (2017). Parki tematyczne na miejskich terenach pokopalnianych Sosnowca i Zielonej Góry. Acta Sci. Pol. Architectura, 16 (1), 65-77. doi: 10.22630/ASPA.2017.16.1.07.

Z uwagi na brak w mieście naturalnych zbiorników wodnych (kilka niewielkich zbiorników sztucznych oraz niedużych strumieni) każdy z obszarów z terenami wodnymi jest dla miasta wyjątkowo cenny. Zbiornik wodny $\mathrm{z}$ jego bezpośrednim otoczeniem stanowią w koncepcji część centralną obszaru. Potencjał rekreacyjno-wypoczynkowy tej części jest znaczny $\mathrm{z}$ uwagi na obecne w bezpośrednim sąsiedztwie dwa osiedla mieszkaniowe i połączenie z trzecim osiedlem ścieżką rowerowo-pieszą. W dalszej części od zbiornika występują lasy, częściowo porastające hałdy cegielni, a częściowo dawne tereny pokopalniane, z wieloma zapadliskami czyniącymi ten teren na swój sposób malowniczym.

W koncepcji zaproponowano wydzielenie obszarów cząstkowych: zbiornika i jego bezpośredniego otoczenia, terenów pokopalnianych, parku leśnego poza terenami pokopalnianymi i osiedla mieszkaniowego Na Cegielni (rys. 6).

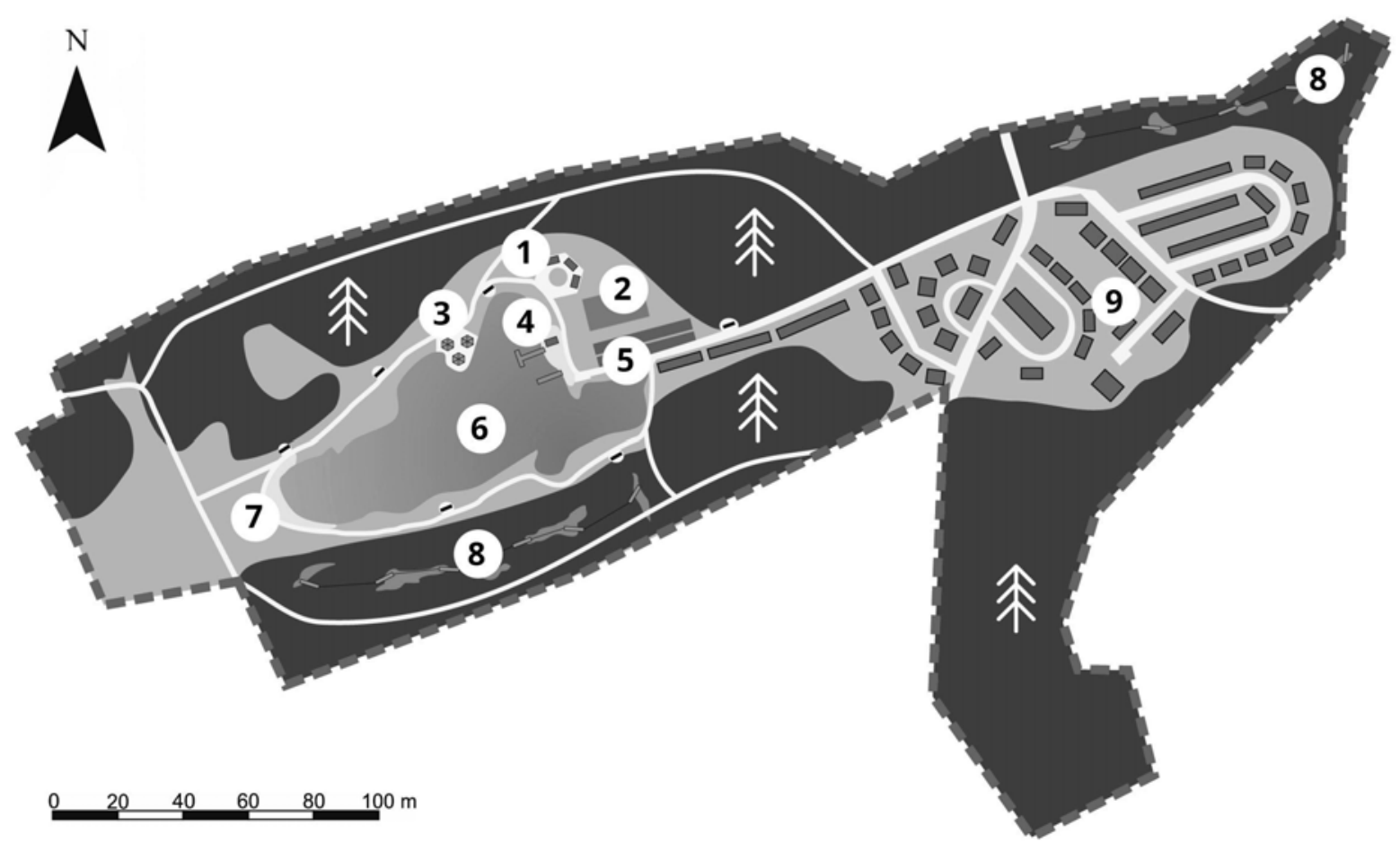

Rys. 6. Koncepcja zagospodarowania terenów pokopalnianych w Zielonej Górze: 1 - strefa usługowa, 2 - pomnik przeszłości przemysłowej, 3 - przebudowana strefa wypoczynku, 4 - wypożyczalnia sprzętu wodnego, 5 - parking, 6 - zbiornik wodny, 7 - plaża, 8 - park linowy, 9 - osiedle Na Cegielni

Fig. 6. The post-mine area development design in Zielona Góra: 1 - service zone, 2 - industrial monument, 3 - rebuilt recreation zone, 4 - water equipment rental, 5 - parking, 6 - water reservoir, 7 - beach, 8 - rope park, 9 - housing estate At The Brickyard

Zbiornik pokopalniany ma dużą wartość zarówno przyrodniczą, wynikającą z podtrzymywania różnorodności biologicznej oraz łagodzenia mikroklimatu, krajobrazotwórczą, jak i użytkową, wynikającą z oferowanych tu przyszłych usług. Od strony wschodniej zbiornika zaplanowano przestrzeń dla małej gastronomii, wypożyczalni rowerów wodnych i kajaków, w anturażu terenu zieleni kształtowanej. W sektorze tym konieczne będzie także wygenerowanie miejsc parkingowych z myślą o gościach z innych części miasta niż bezpośrednio przyległe do zbiornika. W północnej części, na charakterystycznym cyplu, przebudowie ulegnie 
Drozdek, M. E., Greinert, A., Kostecki, J., Tokarska-Osyczka, A. i Wasylewicz, R. (2017). Parki tematyczne na miejskich terenach pokopalnianych Sosnowca i Zielonej Góry. Acta Sci. Pol. Architectura, 16 (1), 65-77. doi: 10.22630/ASPA.2017.16.1.07.

miejsce spotkań osób wypoczywających. Od strony zachodniej istniejący duży teren będzie można zagospodarować jako plażę z bezpiecznym dostępem do brzegu zbiornika.

Część południowa jest ciekawa z uwagi na przeszłość związaną z górnictwem węgla brunatnego. Obecne są tu deniwelacje terenu w postaci zapadlisk, wkomponowujących się w naturalny stok północny Wału Zielonogórskiego. Tworzy to złożoną rzeźbę terenu, o dużym potencjale rekreacyjnym (planowane elementy parku linowego, mostki i kładki). Elementy podobnie urzeźbione występują jeszcze w części obszaru od strony ulicy Łużyckiej, na wschód od ulicy Ceramicznej i w części terenu w sektorze ulic Keramzytowej i Xawerego Dunikowskiego. Ich zagospodarowanie rekreacyjne byłoby podobne do wcześniej opisywanej części pokopalnianej, związanej z wydobyciem węgla brunatnego.

Pozostałe fragmenty opisywanego obszaru mają w układzie współczesnym charakter leśny i taki zostałby po jego modyfikacji. Na terenach leśnych uczytelniono by układ ścieżek pieszo-rowerowych, poprawiając też ich nawierzchnię, głównie w podmokłych zagłębieniach terenu.

Dla odzwierciedlenia przemysłowej przeszłości tego obszaru zostaną użyte istniejące wciąż maszyny pracujące niegdyś w kopalni, a dziś stojące w mało atrakcyjnych miejscach, niedających możliwości podkreślenia ich uroku. Planuje się także umiejscowienie w różnych punktach terenu plansz informacyjnych ilustrujących przeszłość kolejnych miejsc. Istotnym elementem będzie także odpowiednie zorganizowanie strefy usługowej przy zbiorniku wodnym, która powinna w wielu elementach nawiązywać do przeszłości terenu, np. przez zastosowanie elementów przemysłowych przy obiektach oraz w wystroju wnętrz.

Osobnym elementem przestrzennym opisywanego obszaru jest osiedle zabudowy jednorodzinnej, szeregowej, wzbogaconej o blok mieszkalny urządzony w dawnym budynku pieca do wypalania cegieł (piec Hoffmana). Ich obecność, poza tym jednym budynkiem, jest niezwiązana z historią terenu. Dawne budynki cegielni i kopalni węgla zostaną odzwierciedlone na zdjęciach historycznych, ukazanych na planszach rozmieszczonych w wybranych punktach terenu parkowego.

\section{DYSKUSJA}

Oba przedstawione obszary związane były historycznie z przemysłem wydobywczym surowców mineralnych - węgla kamiennego, węgla brunatnego i iłów. Obszar zielonogórski dodatkowo związany był z przetwórstwem iłów - z wyrobem cegieł.

Tereny kopalni lokalizowane były historycznie zarówno poza ośrodkami miejskimi, jak w miastach, co związane było z warunkami naturalnymi (występowanie surowca, dostęp do złoża) oraz dostępnością siły roboczej. Wiele kopalń powstało na terenach obecnej Polski jeszcze w XIX wieku lub na początku XX wieku, ale większość w XX wieku zakończyła eksploatację złóż. Pozostały po nich rozległe tereny, o wadliwej strukturze wewnętrznej i kłopotliwych relacjach przestrzennych z otoczeniem. Zaproponowane formy przyrodniczego (parkowego) zagospodarowania opisywanych terenów wychodzą naprzeciw życzeniom mieszkańców osiedli zlokalizowanych w ich sąsiedztwie. Jest to bardzo ważny element tzw. partycypacyjnego modelu rewitalizacji terenów miejskich, polegającego na szerokim uczestnictwie społeczności lokalnych w fazie planowania działań przez specjalistów (Lorber, 2014; Atkinson i in., 2014; Leszkowicz-Baczyński, 2015; Muszyńska-Jeleszyńska, 2015; Greinert i Drozdek, 2015). Niemniej, w wielu przypadkach można zauważyć brak zainteresowania mieszkańców losami terenów poprzemysłowych, jako - jak napisał Domański (2009) - „nieoswojonej przestrzeni”, co ułatwia nieraz podejmowanie zaplanowanych działań. Pozostając jednak w pewnej opozycji do tego zdania, należy zauważyć wyjątkową w naszym społeczeństwie chęć krytyki zastosowanych rozwiązań „post factum”, nawet w sytuacji wcześniejszego jej nieartykułowania. W opisywanych sytuacjach w bezpośredniej odległości od terenów pokopalnianych ulokowane są osiedla mieszkaniowe, czego efektem jest większa chęć mieszkańców do udziału w pracach nad rewitalizacją nieużytków. 
W obu opisywanych sytuacjach brak jest miejscowych planów zagospodarowania przestrzennego. Wiele elementów ujmowanych w kreowanych koncepcjach planistycznych opiera się więc na zapisach studiów uwarunkowań i kierunków zagospodarowania przestrzennego. Ciesiółka i Rogatka (2015) wskazali na kluczową rolę dokumentacji planistycznej w zakresie polityki rewitalizacji. Jest ona podstawowym narzędziem rekultywacji i rewitalizacji obszarów zdegradowanych. Nieobecność jasnych wskazań w zakresie architektury i zagospodarowania przestrzeni znacząco utrudnia wskazanie docelowych funkcji, zarówno dla części obszaru rewitalizowanego, jak i dla kształtu całości. Wywołuje to m.in. ryzyko niedopasowania zaproponowanych form przestrzennych do realizowanych w przyszłości zadań. Szczególnie istotne może być to wobec terenów przyległych do terenów zabudowy mieszkalnej i usługowej, których presja wobec terenów przyległych może być zgubna dla spójności terenu rewitalizowanego.

Zaproponowane koncepcje doskonale wpisują się w opisywaną w literaturze ideę kształtowania pasm zieleni miejskiej (greenways) - Searns (1995). Znane sa w tym zakresie zmiany doprowadzające do przekształcania byłych terenów przemysłowych w parki miejskie, np. IBA Emscher Park - Duisburg-Nord Industrial Landscape Park, Landschaftspark Duisburg-Nord (Wiegandt, 2000; Labelle, 2001; GTZ, 2003), Ferropolis k. Dessau (Rymar, 2012), Phoenix Dortmund (Maciejewska i Turek, 2014).

W obu opisywanych przypadkach węgiel wydobywano metodą głębinową, powodującą szereg form degradacji terenu, związanych z wydobyciem, przetwarzaniem i ekspedycją surowca, a także współczesnym tworzeniem się zapadlisk na dawnych chodnikach kopalni. Materiał do produkcji cegieł w Zielonej Górze wydobywano natomiast odkrywkowo, czego rezultatem jest obecność wyrobiska i hałd. Odkrywkowe wydobycie wegla brunatnego i surowców mineralnych na potrzeby budownictwa jest jednym z największych sprawców wieloczynnikowej degradacji środowiska (Huculak, 2009; Greinert, 2015). Niestabilność gruntu wyklucza formy zagospodarowania związane z budownictwem kubaturowym. Zagospodarowanie parkowe czy parkowo-leśne jest mniej wrażliwe na tego rodzaju wady terenowe, aczkolwiek i w tym przypadku należy starannie zaplanować nasadzenia, lokalizację obiektów parkowych i dróg dla zmniejszenia ryzyka ich zniszczenia oraz eliminacji ryzyka dla użytkowników.

Przyrodniczo zagospodarowane tereny dawnych kopalni obecne są w różnych miastach europejskich, $w$ tym także polskich. Jest to wiodący kierunek realizowany w miastach Górnego Śląska i Zagłębia Dąbrowskiego (Będzin, Bytom, Dąbrowa Górnicza, Katowice, Ruda Śląska, Sosnowiec, Tychy), ale wskazywać można także na przykłady z Krakowa - Park Bednarskiego wykorzystujący dawny kamieniołom, Rzeszowa i Opola - żwirownie, Wrocławia - glinianki (Huculak, 2009), niemieckiego Zagłębia Ruhry, np. w Gelsenkirchen, czy francuskiego regionu Calle (Greinert, 2000). Pomysł powiązania przeszłości przemysłowej związanej z produkcją cegieł ze współczesnym zagospodarowaniem przyrodniczo-turystycznym terenu także nie jest nowy. W Poczdamie zaproponowano włączenie glinianek, budowli dawnych cegielni i zabytków budownictwa ceglanego do turystycznej trasy tematycznej Havelländische Ziegeltour (Kwaśniewski, 2004).

Idea współczesnych greenways zakłada introdukcję myśli historycznej i społecznej w ogólną funkcjonalność rekreacyjną terenów zieleni miejskiej (Searns, 1995; Małuszyńska, Małuszyński i Ancuta, 2014). W tej mierze istotne są elementy historyczne związane z industrialną przeszłością miasta i jego części, np. poprzez organizację ścieżek tematycznych - Route of Industrial Culture (Szlak Dziedzictwa Przemysłowego) i pomników przemysłu - industrial monuments (Labelle, 2001), industrial heritage (Ozden, 2012). Programami rewitalizacji (regeneracji) terenów poprzemysłowych, jako spuścizny kulturowej, obejmowane są tereny pod pojedynczymi budynkami, przez obszary pojedynczych zakładów, aż po całe strefy przemysłowe (Ozden, 2012). Według kryteriów UNESCO, ICOMOS (The International Council on Monuments and Sites) oraz TICCIH (The International Committee for the Conservation of Industrial Heritage) mają one ogromne znaczenie dla historii Europy (Decision 32 COM 8B.46, 2009; ICOMOS, 2011). Bardzo liczne tereny i obiekty przemysłowe w Polsce, którym po czasach industrialnych nadano funkcje kulturalne lub/i handlowe, opisano w monografii na temat rewitalizacji miast polskich (Huculak, 2009). 
Drozdek, M. E., Greinert, A., Kostecki, J., Tokarska-Osyczka, A. i Wasylewicz, R. (2017). Parki tematyczne na miejskich terenach pokopalnianych Sosnowca i Zielonej Góry. Acta Sci. Pol. Architectura, 16 (1), 65-77. doi: 10.22630/ASPA.2017.16.1.07.

W pamięci społeczności lokalnych istnieje jednak sentyment do minionej przeszłości. Dotyczy to zarówno dawnych pracowników nieistniejących zakładów przemysłowych i ich rodzin, jak i innych osób szukających szczególnych cech swoich małych ojczyzn. Tereny parkowe są wyjątkowo dobre dla krzewienia opisywanych idei ze względu na otoczenie sprzyjające wyciszeniu, kontemplacji i oderwaniu od codzienności.

\section{PODSUMOWANIE}

Koniecznym elementem rozważań nad docelowym zagospodarowaniem obszarów poprzemysłowych jest analiza funkcjonalno-przestrzenna, a także analiza ryzyka związanego $\mathrm{z}$ ich użytkowaniem na terenach powydobywczych, w sposób szczególny uwzględniającego niestabilność gruntów. Dokonanie jej dla terenów zlokalizowanych w Sosnowcu i Zielonej Górze pozwoliło wskazać na parkowe użytkowanie terenu jako dla nich optymalne.

Dla uzyskania nowej funkcjonalności terenów poprzemysłowych, akceptowalnej społecznie i właściwej pod względem formalno-prawnym i gospodarczym, konieczne jest przeprowadzenie ich rekultywacji.

Nowa funkcjonalność powinna zakładać zgodność z ideą kształtowania pasm zieleni miejskiej oraz tworzenia trwałych relacji społecznych poprzez utrzymanie w świadomości ludzi osiągnięć kultury przemysłowej miasta/regionu.

Parki tematyczne, skonstruowane jako wielofunkcyjne obszary wypoczynkowo-rekreacyjne, z uwypukleniem elementów po dawnych zakładach przemysłowych, są ciekawą propozycją dla osób w różnym wieku. O dobrym ich odbiorze decyduje jednak ładunek sentymentalny wobec czasów pamiętanych, lecz jednak już minionych.

\section{PIŚMIENNICTWO}

Atkinson, G., Doick, K. J., Burningham, K. i France, C. (2014). Brownfield regeneration to greenspace: Delivery of project objectives for social and environmental gain. Urban Forestry \& Urban Greening, 13, 586-594. doi: 10.1016/ j.ufug.2013.04.002.

Baborska-Norożny, M. (2012). Rewitalizacja terenów poprzemysłowych - modele przekształceń na wybranych przykładach. Architektura - Czasopismo Techniczne, 3-A, 109(12), 275-279.

Bujkiewicz, Z. (1997). Kopalnia węgla brunatnego w Zielonej Górze. Studia Zielonogórskie, 3, 79-88.

Ciesiółka, P. i Rogatka, K. (2015). Rola miejscowych planów zagospodarowania przestrzennego w procesie rewitalizacji miast na przykładzie metropolii Poznań. Problemy Rozwoju Miast, 12(4), 27-36.

De Sousa, C. i Ghoshal, S. (2012). Redevelopment of brownfield sites. Metropolitan sustainability: Understanding and improving the urban environment (strony 99-117). Woodhead Publ. Ltd.

Decision 32 COM 8B.46 (2009). Changes to criteria of properties inscribed on the World Heritage List. World Heritage Committee. United Nations.

Dej, M., Huculak, M., Janas, K., Jarczewski, K. i Ziobrowski, Z. (2013). Rewitalizacja obszarów zdegradowanych w miastach - propozycje zmian prawnych. Część II. Propozycje zapisów Krajowej Polityki Miejskiej w zakresie rewitalizacji, które moga być realizowane w okresie programowania polityki spójności 2014-2020. Ekspertyza przygotowana na zlecenie Ministerstwa Rozwoju Regionalnego przez pracowników. Kraków: Instytut Rozwoju Miast.

Domański, B. (2000). Restrukturyzacja terenów poprzemysłowych w miastach. W Z. Ziobrowski, D. Ptaszycka-Jackowska, A. Rębowska i A. Geissler (red.), Rewitalizacja. Rehabilitacja. Restrukturyzacja. Odnowa miast (strony 107-142). Kraków: Instytut Rozwoju Miast.

Domański, B. (2009). Rewitalizacja terenów poprzemysłowych - specyfika wyzwań i instrumentów. W W. Jarczewski (red.), Przestrzenne aspekty rewitalizacji - śródmieścia, blokowiska, tereny poprzemysłowe, pokolejowe i powojskowe. Rewitalizacja miast polskich. Tom 4 (strony 125-138). Kraków: Instytut Rozwoju Miast.

Frantál, B., Greer-Wootten, B., Klusácek, P., Krejcí, T., Kunc, J. i Martinát, S. (2015). Exploring spatial patterns of urban brownfields regeneration: The case of Brno, Czech Republic. Cities, 44, 9-18. doi: 10.1016/j.cities.2014.12.007. 
Drozdek, M. E., Greinert, A., Kostecki, J., Tokarska-Osyczka, A. i Wasylewicz, R. (2017). Parki tematyczne na miejskich terenach pokopalnianych Sosnowca i Zielonej Góry. Acta Sci. Pol. Architectura, 16 (1), 65-77. doi: 10.22630/ASPA.2017.16.1.07.

Gallagher, F. J., Pechmann, I., Holzapfel, C. i Grabosky, J. (2011). Altered vegetative assemblage trajectories within an urban brownfield. Environmental Pollution, 159, 1159-1166. doi: 10.1016/j.envpol.2011.02.007.

Gontaszewska, A. (2015). Eksploatacja węgla brunatnego w regionie lubuskim; Region zielonogórski. W A. Greinert (red.), Wydobycie węgla brunatnego i rekultywacja terenów pokopalnianych w regionie lubuskim. Zielona Góra: Wydawnictwo IIŚ WBAIŚ UZ.

Greinert, A. (2000). Ochrona i rekultywacja terenów zurbanizowanych. Monografia 97. Zielona Góra: Wydawnictwo Politechniki Zielonogórskiej.

Greinert, A. (2015). Rekultywacja terenów pokopalnianych w regionie lubuskim. W A. Greinert (red.), Wydobycie węgla brunatnego i rekultywacja terenów pokopalnianych w regionie lubuskim (strony 204-208). Zielona Góra: Wydawnictwo Instytutu Inżynierii Środowiska Uniwersytetu Zielonogórskiego.

Greinert, A. i Drozdek, M.E. (2015). „Zielona”Zielona Góra - Strategia rozwoju terenów zieleni w mieście Zielona Góra. Zielona Góra: Wydawnictwo IIŚ WBAIŚ UZ.

GTZ (2003). Podręcznik rewitalizacji. Zasady, procedury i metody działania wspótczesnych procesów rewitalizacji. 14. Restrukturyzacja obszarów poprzemystowych i powojskowych w Niemczech (strony 136-144). Gesellschaft für Technische Zusammenarbeit. Warszawa: Mefisto Editions.

Huculak, M. (2009). Rewitalizacja terenów poprzemysłowych. Polskie doświadczenia i perspektywy. W W. Jarczewski (red.), Przestrzenne aspekty rewitalizacji - śródmieścia, blokowiska, tereny poprzemysłowe, pokolejowe i powojskowe. Rewitalizacja miast polskich. Tom 4 (strony 139-198). Kraków: Instytut Rozwoju Miast.

ICOMOS (2011, July). Draft Joint ICOMOS - TICCIH Principles for the Conservation of Industrial Heritage Sites, Structures, Areas and Landscapes. "The Dublin Principles" Final draft integrating comments received from the ICOMOS Advisory and Executive Committees, for distribution to the ICOMOS membership in view of submission to the $17^{\text {th }}$ ICOMOS General Assembly. ICOMOS News.

Jarczewski, W. (2009). Skala degradacji miast w Polsce. W W. Jarczewski (red.), Przestrzenne aspekty rewitalizacji - śródmieścia, blokowiska, tereny poprzemystowe, pokolejowe i powojskowe. Rewitalizacja miast polskich. Tom 4 (strony 15-24). Kraków: Instytut Rozwoju Miast.

Kozińska, A. M. i Greinert, A. (2013). Koncepcja rekultywacji i zagospodarowania części terenu po byłej Kopalni Węgla Kamiennego „Niwka” w Sosnowcu. Przeglad Budowlany, 3, 82-85.

Kwaśniewski, A. (2004). Upiększanie wyspy Poczdam. Dziedzictwo w służbie przyszłości. W A. Drapella-Hermansdorfer (red.), Ksztaltowanie krajobrazu: idee, strategie, realizacje. Część I. Saksonia, Brandenburgia, Berlin (strony 72-75). Wrocław: Oficyna Wydawnicza Politechniki Wrocławskiej.

Labelle, J. M. (2001). Emscher Park, Germany - expanding the definition of a "park". W Harmon, D. (red.), Crossing Boundaries in Park Management: Proceedings of the $11^{\text {th }}$ Conference on Research and Resource Management in Parks and on Public Lands (strony 222-227). Michigan: The George Wright Society.

Leszkowicz-Baczyński, J. (2015). Rewitalizacja społeczna jako odpowiedź na problemy obszarów miejskich. Acta Universitatis Lodziensis, Folia Sociologica, 52, 95-108.

Lorber, L. (2014). Holistic approach to revitalised old industrial areas. The $3^{\text {rd }}$ International Geography Symposium - GEOMED2013. Procedia - Social and Behavioral Sciences, 120, 236-334.

Lorens, P. (2010). Rewitalizacja miast planowanie i realizacja. Współczesne tendencje rozwoju struktur miejskich. Znaczenie procesów przekształceń i rewitalizacji. W P. Lorens i J. Martyniuk-Pęczek (red.), Wybrane zagadnienia rewitalizacji miast (strony 10-19). Gdańsk: Wydawnictwo Urbanista.

Maciejewska, A. i Turek, A. (2014). Rewitalizacja obszarów poprzemysłowych ze szczególnym uwzględnieniem uwarunkowań środowiska przyrodniczego - wybrane studia przypadków. Problemy Rozwoju Miast, II, 81-94.

Małuszyńska, I., Małuszyński, M. J. i Ancuta, M. (2014). Rewitalizacja terenów poprzemysłowych m.st. Warszawy na przykładzie Powiśla. Przeglad Naukowy Inżynieria i Kształtowanie Środowiska, 63, 99-109.

Muszyńska-Jeleszyńska, D. (2015). Znaczenie konsultacji społecznych w procesach rewitalizacji obszarów miejskich. Ruch Prawniczy, Ekonomiczny i Socjologiczny, LXXVII, 1, 257-271.

Muszyńska-Jeleszyńska, D. i Jasińska, M. (2013). Rewitalizacja terenów poprzemysłowych w Europie Środkowej - doświadczenia projektu Cobraman. Problemy Rozwoju Miast, III, 95-104.

Ozden, P. (2012). Culture-led regeneration projects in post-industrial areas: The Istanbul experience. The Sustainable City VII, 2, WIT Transactions on Ecology and The Environment, 155, 823-834. 
Drozdek, M. E., Greinert, A., Kostecki, J., Tokarska-Osyczka, A. i Wasylewicz, R. (2017). Parki tematyczne na miejskich terenach pokopalnianych Sosnowca i Zielonej Góry. Acta Sci. Pol. Architectura, 16 (1), 65-77. doi: 10.22630/ASPA.2017.16.1.07.

Pancewicz, A. (2012). Poszukiwanie nowego krajobrazu obszarów poprzemysłowych. Architektura Krajobrazu, Nowe tendencje w ksztattowaniu krajobrazu, 1, 41-49.

PFE (2016). Lista projektów realizowanych z Funduszy Europejskich w Polsce w latach 2014-2020. Portal Funduszy Europejskich. Pobrano z lokalizacji: http://www.funduszeeuropejskie.gov.pl/strony/o-funduszach/projekty/lista-projektow/ lista-projektow-realizowanych-z-funduszy-europejskich-w-polsce-w-latach-2014-2020

Rymar, M. (2012). Rewitalizacja terenów postindustrialnych na przykładzie Zagłębia Ruhry. Materiały Ochrona środowiska jako warunek rozwoju rejonu tarnobrzeskiego. Rzeszów: WIOŚ. Pobrano z lokalizacji: http://www.wios.rzeszow. $\mathrm{pl} / \mathrm{cms} / \mathrm{upload} / \mathrm{edit} / \mathrm{file} / 4 . \mathrm{pdf}$

Searns, R. M. (1995). The evolution of greenways as an adaptive urban landscape form. Landscape and Urban Planning, 33, 65-80. doi: 10.1016/0169-2046(94)02014-7.

Skalny, A. i Białecka, B. (2015). Kierunki przekształceń terenów przemysłowych - analiza przypadków. Zeszyty Naukowe Politechniki Ślaskiej, Seria Organizacja i Zarządzanie, 821940, 227-239.

Studium (2008, 2014). Studium uwarunkowań i kierunków zagospodarowania przestrzennego. Uchwała nr LXIV.556.2014 Rady Miasta Zielona Góra z dnia 25 marca 2014 r.

Uchwała Nr 177/XIV/03 Rady Miejskiej w Sosnowcu z dnia 25 września 2003 roku w sprawie: przyjęcia „Zmiany studium uwarunkowań i kierunków zagospodarowania przestrzennego gminy Sosnowiec”.

Wiegandt, C. C. (2000). Urban development in Germany - perspectives for the future. GeoJournal, 50, 5-15. doi: 10.1023/ A:1007107013751.

\title{
THEMATIC PARKS IN URBAN POST-INDUSTRIAL AREAS
}

\begin{abstract}
In the paper it has been shown the possibilities of post-mining areas development in the two Polish mid-sized cities - Sosnowiec and Zielona Gora. The area in Sosnowiec includes part of the former "Niwka" coal mine while in Zielona Gora - former "Krośnieńska" brickyard and lignite mines operating within the Consolidierte Grünberger Gruben company. Today, the both areas are wasteland, with a strong degradation of the soil surface. Authors of this paper have proposed for the described areas the new development as a park with elements from their industrial past. Thus, in addition to recreation and leisure, the areas will have the interesting, unique features of thematic parks referring to history of the cities.
\end{abstract}

Key words: post-industrial areas, revitalization, deindustrialization, municipal green 